\title{
The Relationship between Preeclampsia with the Occurrence of Postpartum Depression in Masyita Delivery Hospital Makassar, Indonesia
}

\author{
Wa Mina La Isa ${ }^{1}$, Ernawati ${ }^{2}$, Amriati M. ${ }^{3}$, Rusni M. ${ }^{4}$, Sitti Nurbaya ${ }^{5}$, M. Askar ${ }^{6}$ \\ ${ }^{1}$ Lecturer, ${ }^{2}$ Assistant Professor, ${ }^{3}$ Assistant Professor, ${ }^{5}$ Assistant Professor in STIKES Nani Hasanuddin Makassar, \\ Indonesia, ${ }^{4}$ Lecturer, in Nursing Department of Health Polytechnic of Ministry of Health in Makassar, Indonesia, \\ ${ }^{6}$ Assistant Professor, in Nursing Department \& Researcher in the Center of Excellent on Urban Health of Ministry \\ of Health in Makassar, Indonesia
}

\begin{abstract}
Preeclampsia in Indonesia remains a huge problem during pregnancy with high morbidity and mortality. Many risk factors influence the occurrence of preeclampsia, such as the family history of preeclampsia, kidney disease, diabetes mellitus, chronic hypertension that has been suffered previously by pregnant mothers before pregnancy (preeclampsia superimposed), obesity, and postpartum depression. The research objective was to determine the relationship between preeclampsia and the occurrence of postpartum depression in Masyita Delivery Hospital Makassar. This study used quantitative research method with a cross-sectional design. Sampling using purposive sampling with a sample size of 61 postpartum mothers. Collecting data using a questionnaire and analyzed using the Chi-Square test. This study found that pregnant mothers who experienced mild preeclampsia were 34 subjects with $8.8 \%$ of them had postpartum depression, severe preeclampsia experienced by 7 subjects with $71,4 \%$ of them had postpartum depression. The results of statistical tests using Chi-square obtained the $\mathrm{p}$-value $=0.001$. This study concluded that there is a significant relationship between preeclampsia and the incidence of postpartum depression in Masyita Delivery Hospital Makassar, Indonesia.
\end{abstract}

Keywords: Postpartum depression, preeclampsia.

\section{Introduction}

Preeclampsia is a group of symptoms arising during pregnancy, childbirth, and clinically manifested by hypertension, edema, and proteinuria, and usually appear at 20 weeks of gestation and persisted until the end of the first week after delivery. Preeclampsia is a pregnancy disorder with high morbidity and mortality. The appropriate cause of preeclampsia is still unknown, but there are risk factors that are considered related to the incidence of preeclampsia. Those risk factors which

\section{Corresponding Author:}

\section{Askar}

Health Polytechnic of Makassar, Jl. Banta-Bantaeng No. 46, Makassar, South Sulawesi, Indonesia. 90222 e-mail: askar@poltekkes-mks.ac.id

Mobile No.: 085299947722 is linked with the occurrence of preeclampsia, such as a family history of preeclampsia, kidney disease, diabetes mellitus, chronic hypertension that has been suffered before pregnancy (superimposed preeclampsia), obesity, and postpartum depression. ${ }^{1}$

Global Burden Diseases (GBD) found in pregnancy with hypertension were in 1990 ranked $75^{\text {th }}$, this disorder responsible for $6 \%$ of the burden in all of the maternal condition.

The Data also showed that preeclampsia responsible for $16 \%$ of maternal mortality rate in the developing countries, $9 \%$ in Africa, $26 \%$ in the Caribbean, and Indonesia estimated at least $7-10 \%{ }^{2}$ The incidence of preeclampsia in Indonesia was $3-10 \%$ in $2012^{3}$ and found that maternal and child mortality rate in preeclampsia about $24 \%$ of $58,1 \%$. Indonesia had increased preeclampsia by about $15-25 \%{ }^{4}$ 
Health Profile Data of South Sulawesi Province in 2013 showed that preeclampsia becomes the $2^{\text {nd }}$ caused by maternal mortality rate in South Sulawesi and estimated about 28\%. ${ }^{5}$ Another research reported that the incidence rate in Makassar, the main city in South Sulawesi showed data 120 cases in 2011, 146 cases in 2013, and 81 cases $2016 .{ }^{6}$

Preeclampsia is not the direct cause of maternal mortality but this affects the occurrence of postpartum depression. The research ${ }^{7}$ showed that $26,67 \%$ of postpartum depression was caused by preeclampsia and it is estimated that about 10 pregnant women per 1000 live birth would experience mild preeclampsia and 30-200 pregnant women per 1000 live birth would experience severe preeclampsia.

The incidence of postpartum depression in India was $8,5 \%$, Malaysia $3,9 \%$, Taiwan $40 \%$, and Indonesia $11.3 \%$. The research ${ }^{8}$ reported the incidence of postpartum depression range between $16-22,35 \%$. The initial study by the researcher in Delivery Hospital Masyita in Makassar found 26 cases of postpartum depression during 2017, 30 cases during 2018, and 16 cases found in January up to April 2019.

\section{Materials and Method}

This research design using a quantitative study with a cross-sectional approach. This study was conducted in Delivery Hospital Masyita in Makassar started from June up to July 2019. The research population was postpartum women with a history of preeclampsia. The total sample participated in this study were 41 women obtained by accidental sampling.

The inclusion criteria of the sample were postpartum women with a history of preeclampsia, declare their agreement to participate in this study, could understand and fill in the questionnaire, and showed a cooperative attitude during the research. The exclusion criteria were the postpartum women had not complete to fill in all the research questionnaire.

Data collection is an approach process to the subject and subject characteristic collection process required in a study. ${ }^{9}$ Data collection in this study was conducted in Delivery Hospital Masyita in Makassar. Data were collected by using a questionnaire.

The collected questionnaire before analysis was checked by the researcher to ensure all of the questions were answere $\mathrm{d}$ by subjects. The incomplete questionnaire was removed and dropped out. Data then coded manually and then entered into table data as its group and purposes.

Data was analyzed univariately to have a brief description of each research variable. Bivariate analysis was performed to explain the correlation between independent and dependent variables. The data were analyzed using the Chi-square test.

\section{Results}

The results of this study were presented in the table below:

Table 1. Characteristic of subjects in Delivery Hospital Masyita Makassar $(n=41)$.

\begin{tabular}{|l|c|c|}
\hline Demographic Data & 61 & $\%$ \\
\hline Age & 3 & 7.3 \\
\hline$\leq 19$ years old & 28 & 68.3 \\
\hline $20-29$ years old & 10 & 24.4 \\
\hline $30-39$ years old & 11 & 26.8 \\
\hline Parity & 28 & 68.3 \\
\hline Primiparity & 2 & 4.9 \\
\hline Multiparity & 32 & 78.0 \\
\hline Grand multiparity & 9 & 22.0 \\
\hline Abortion history & \multicolumn{2}{|l}{} \\
\hline No & 1 & 2.4 \\
\hline Yes & 5 & 12.5 \\
\hline Level of Education & 5 & 12.5 \\
\hline No School & 22 & 53.7 \\
\hline Elementary school & \multicolumn{2}{|l|}{} \\
\hline Yunior high school & \multicolumn{2}{|l|}{} \\
\hline Senior high school & \multicolumn{2}{|l|}{} \\
\hline University & \multicolumn{2}{|l|}{} \\
\hline
\end{tabular}

Based on Table 1, this study showed that among 41 subjects participated in this study, it was found that dominant of the subject were in the age group 20-29 years old amounted 28 subjects $(68.3 \%)$ and the least in age group $<19$ years old amounted 3 subjects $(7.3 \%)$. Parity of subject distributed dominantly were multiparity were 28 subjects (68.3\%) and the least was Grand multiparity amounted 2 subjects (4.9\%).

Characteristic subjects regarding abortion history found that 32 subjects had no history and there were 
9 subjects has abortion history. The education level of subjects dominantly was graduated from Senior high school 22 subjects $(53.7 \%)$ and the least were no school 1 subject $(2.4 \%)$.

Table 2. The relation of preeclampsia and the occurrence of postpartum depression in Delivery Hospital Masyita Makassar

\begin{tabular}{|l|c|c|c|c|c|c|}
\hline \multirow{2}{*}{ Preeclampsia } & \multicolumn{3}{|c|}{ Postpartum depression } & \multicolumn{2}{|c|}{ Total } \\
\cline { 2 - 7 } & \multicolumn{2}{|c|}{ Yes } & \multicolumn{2}{c|}{ No } & \multicolumn{2}{|c|}{} \\
\cline { 2 - 7 } & $\mathbf{n}$ & $\%$ & $\mathbf{n}$ & $\%$ & $\mathbf{n}$ & $\%$ \\
\hline Mild & 3 & 8.8 & 31 & 91.2 & 34 & 100.0 \\
\hline Severe & 5 & 71.4 & 2 & 28.6 & 7 & 100.0 \\
\hline Total & 8 & 19.5 & 33 & 80.5 & 41 & 100.0 \\
\hline $\mathrm{p}=0.015, \alpha=0.05$ &
\end{tabular}

Based on Table 2, this study found statistically by Chi-square test the significant $(\mathrm{p}=0.015)$ relation between preeclampsia and postpartum depression occurrence in Delivery hospital Masyita Makassar $(\mathrm{p}<\alpha=0.05)$.

\section{Discussion}

Based on this study conducted in Delivery Hospital Masyita Makassar, it was shown that there was a significant correlation between preeclampsia and postpartum depression. Pregnant women with severe preeclampsia more experience postpartum depression than mild preeclampsia, while pregnant women with mild preeclampsia dominantly were in the mild category of preeclampsia.

Nevertheless, three subjects had mild preeclampsia but also experienced postpartum depression. This was may occur because of their level of education dominantly in Senior high school. Pregnant women with a high level of education more are opened with an idea and information about any changes for getting proportional health services and realized the benefit of health services they received. ${ }^{10}$ Level of education also determined the ease of understanding the information and knowledge about the baby delivery process they received. Thus, the older the gestational age approaching the delivery process, the more mother could prepare mature psychology to reduce the burden on the mother's thinking. ${ }^{11}$

This study also found two subjects with severe preeclampsia but not experienced postpartum depression. This was maybe occurred because of their age and experience with the previous pregnancy. Age is related to a person's maturity. ${ }^{12}$ Maturity is technical maturity in carrying out tasks as well as psychological maturity. The older a person is, the more his technical and psychological maturity will also increase, as well as showing mental maturity. Increasing age will increase the policy of a person's ability to make decisions, think rationally, control emotions, and tolerate the views of others.

Age is related to the psychological state of the mother. Mothers with the age of 20-35 years will be calmer in facing childbirth and the puerperium because the age is considered safe for pregnancy and childbirth. After all, the physical conditions, especially the reproductive and psychological organs, are $100 \%$ ready to face pregnancy, childbirth, and the puerperium. ${ }^{11}$

This study match with the previous study ${ }^{7}$ found that postpartum depression caused by preeclampsia in women giving birth will indicate mild postpartum depression of about 10 per 1000 live births and severe postpartum depression of 30-200 per 1000 live births.

Preeclampsia is a condition in which hypertension is accompanied by proteinuria, edema, or both that occur as a result of pregnancy after the 20th week or sometimes earlier. There are extensive hydatidiform changes in the villi and chorialis. ${ }^{13}$ Preeclampsia (toxemia gravidarum) is high blood pressure accompanied by proteinuria (protein in the urine) or edema (fluid build-up) that occurs at 20 weeks of pregnancy until the end of the first week after delivery. ${ }^{14}$

Depression is a period of disruption to human function related to feelings of sadness and accompanying symptoms, including changes in sleep and appetite patterns, psychomotor, concentration, anhedonia, fatigue, feelings of hopelessness and helplessness, and suicide. Depression is a mood disorder characterized by loss of feeling of control and subjective experience of severe suffering. The mood is an internal emotional state that permeates a person, and not affects, which is an expression of the emotional content at that time. ${ }^{15}$

Maternal depression is a term used across a spectrum of depressive conditions that can affect both the mother (up to 12 months after delivery) and the expectant mother. These depressive conditions include prenatal depression, postpartum depression, and postpartum psychosis. Maternal depression is increasingly recognized as a public health problem worldwide and 
can affect the lives of individuals which can affect work, family, and the health and development of infants. ${ }^{16}$

Postpartum depression results from preeclampsia. In this condition, postpartum depression that lasts a long time has a negative long-term impact on the development of intellectual behavior. ${ }^{17}$

According to the researcher's opinion, there is a relationship between preeclampsia and the incidence of postpartum depression, because subjects who experience severe preeclampsia are more likely to experience postpartum depression. So it can be concluded that the heavier the preeclampsia experienced by the mother, the higher the potential for the mother to experience postpartum depression. In general, all emotions felt by postpartum women are quite unstable. A pregnant woman can have extreme reactions and her moods often change rapidly. Emotional reactions and perceptions about life can also change, plus the symptoms of preeclampsia are felt.

\section{Conclusion}

Most of the subjects experienced mild preeclampsia at the Delivery Hospital Masyita in Makassar. There was a significant relationship between preeclampsia and the incidence of postpartum depression at the Delivery Hospital Masyita in Makassar. The more severe the preeclampsia condition, the more likely the mother will experience postpartum depression and vice versa, the milder the preeclampsia condition, the less likely the mother will experience postpartum depression.

Pregnant and childbirth mothers need to increase their knowledge and consult with health workers to reduce the possibility of experiencing postpartum depression. Nurses from maternal and child health are more developing an understanding of nursing in overcoming postpartum depression disorder in mothers and making evaluation materials for hospitals to maximize therapeutic communication to pregnant women. Researchers who are interested in this topic need to develop this research by adding variables, samples, and using different method to be able to see a more complete relationship.

Ethical Clearance: The present study was carried out following the research principles. This study implemented the basic principles of ethics of respect, beneficence, nonmaleficence, and justice. This study had been approved by the Ethical Board of Nani Hasanuddin
Makassar Health Science, Document Number. 001/ STIKES-NH/KEPK/I/2019.

Conflict of Interest: There was no report of the conflict of interest involved with this study so far.

Source of Funding: This study was funded by authors.

\section{References}

1. Meeke H, et al. Postpartum Depression After Mild and Severe Preeclampsia. Journal of Women's Health 2011; 20(10):1535-1542.

2. WHO U. UNFPA, World Bank Group, and the United Nations Population Division. Trends in maternal mortality; 1990 to 2015. Estimates by WHO, UNICEF. UNFPA. Geneva: World Bank Group and the United Nations population division; 2015.

3. Ministry of the Health Republic of Indonesia. PWS Report of Maternal and Child Health, Maternal Mortality Rate, Infant Mortality Rate. Available from: http://ilmukebidananstikeskendedesmalang.blogspot.com/2012/11/laporan-pwskiakabkotaaki-akb.html). [Accessed April 25 $5^{\text {th }}$ 2019].

4. Mochtar R. Sinopsis Obstetri. 21 ${ }^{\text {st }}$ Ed.: EGC; 2013.

5. Provincial Health Office of South Sulawesi. Health Profile of South Sulawesi 2013. Available from: http://dinkes.sulselprov.go.id/uploads/info/PK2013.pdf. [Accessed April 15 $5^{\text {th, } 2019] . ~}$

6. Nuning S., Mardiana. Risk factors related to the incidence of preeclampsia in pregnancy (case study in Brebes Regency Hospitals 2014). Unnes Journal of Public Health 2016; 5(2):90-99.

7. Li Chen, et al. Development of Postpartum Depression in Pregnant Women whit Preeclampsia; A Retrospective Study. Journal BioMed Research Internasional 2019;1-7.

8. Zulpatin N, et al. Determinant factor of postpartum depression in East Lombok Subdistrict. Health Research System Bulletin Journal 2017; 20(3): 8995.

9. Nursalam. Nursing science research methodology; Practical approach. $4^{\text {th }}$ Ed.: Salemba Medika. 2016.

10. Hendarti SH. The effect of health education about breastfeeding technique regarding the readiness of giving breastfeeding of primigravida women 
in BPM TRS Sleman. Thesis. 2016, University of Aisyiah Yogyakarta.

11. Rinata, E., \& Andayani, GA. Mother characteristics (age, parity, education) and family support with third-trimester anxiety of pregnant women. Health sciences journal 2018; 16(1): 14-20.

12. Kurniadi, A. Nursing management and it's prospective (theory, concept, and application). Jakarta; FKUI. 2016.

13. Mitayani. Maternity Nursing Care. Jakarta; Salemba Medika. 2009.
14. Manuaba, IBG. Obstetric, gynecology, and family planning. Jakarta; EGC. 1998.

15. Lestari, T. The theory collection for health research literature study. $1^{\text {st }}$ Ed.: Yogyakarta; Nuha Medika. 2015.

16. Shidhaye PR., Giri PA. Maternal depression; a hidden burden in developing countries. Annual medical \& health of science research 2014; 4(4):463-465.

17. Kaplan, et al. Sinopsis psychiatric; the clinical psychiatric science. $1^{\text {st }}$ Ed.: Jakarta; Bina Rupa Aksara. 2007. 